\title{
Design, Synthesis, Molecular Docking and Antibacterial Screening of Some Quinolone Compounds
}

\author{
LUCIA PINTILIE ${ }^{1 *}$, CONSTANTIN TANASE ${ }^{1}$, MARIA MAGANU², \\ MIRON TEODOR CAPROIU ${ }^{2}$ \\ ${ }^{1}$ National Institute for Chemical-Pharmaceutical Research and Development, 112 Vitan Av., 74373, Bucharest, Romania \\ ${ }^{2}$ Organic Chemistry Center "C.D. Nenitescu", 202 B Splaiul Independentei, 060021, Bucharest, Romania
}

\begin{abstract}
Some 6,8-dichloro-quinolone compounds were designed and synthesized; by comparing with 6-fluoro-8-chloro-quinolone compounds, the influence of the nature of the halogen atom from six position of the quinolone ring on the molecular properties and on the antimicrobial activity was studied. The DFT/B3LYP/6-311G* level of basis set was used for the computation of molecular structure of optimized compounds. The calculations of characteristics and molecular properties were performed using Spartan'14 Software from Wavefunction, Inc. Irvine, CA. The HOMO-LUMO energies and orbitals, global reactivity descriptors, various thermodynamic parameters, and dipole moment $(\mu)$ were calculated to determine the molecular properties of quinolone compounds. Molecular docking studies were realized to identify and visualize the most likely interaction ligand (quinolonelfluoroquinolone compounds) with the protein receptor. The score and hydrogen bonds formed with the amino acids from group interaction atoms are used to predict the binding modes, the binding affinities, and the orientation of the docked quinolonelfluoroquinolone derivatives in the active site of the protein receptor. The protein-ligand complex was realized based on the X-ray structure of Bacillus cereus (PDB ID: IVEN) using CLC Drug Discovery Workbench 2.4 software. The quinolone compounds were characterized by physical-chemical methods (elemental analysis, IR spectral analysis, IH-NMR, 13C-NMR spectra, UVVis, thin layer chromatography) and by antimicrobial activity against some Gram-positive and Gramnegative microorganisms: Staphylococcus aureus, Bacillus cereus, Bacillus subtilis, Micrococcus luteus, Escherichia coli and Pseudomonas aeruginosa.
\end{abstract}

Keywords: quinolones, fluoroquinolones, molecular docking, antimicrobial activity

\section{Introduction}

Fluoroquinolone compounds represent one of the extensively utilized antimicrobials. In the previous decades new quinolones have been developed, such as moxifloxacin (1), delafloxacin (2) and finafloxacin (3) which possess a broader spectrum of activity and enhanced bioavailability [1-5].

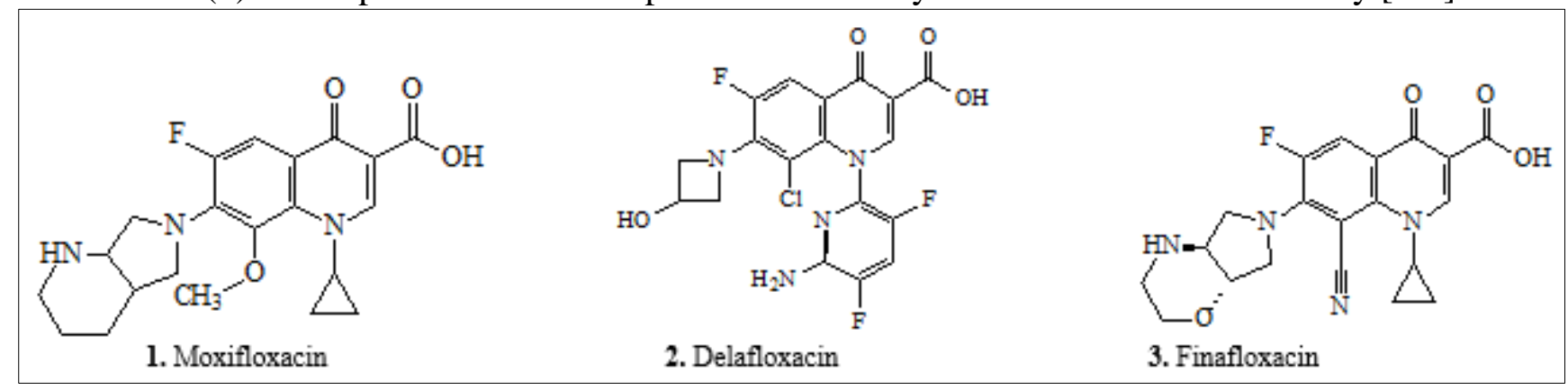

Quinolone derivatives also have other biological activities: antitumor activity [6-11], antimycobacterial activity [5,12-17] and antiviral activity [18-22]. From quinolone derivatives with antitumor activity, voreloxin (7-[(3S,4S)-3-methoxy-4-(methylamino)-1-pyrrolidinyl]-4-oxo-1-(1,3-thiazol-2-yl)1,4-dihydro-1,8-naphthyridine-3-carboxylic acid) (4) is pointed out. Voreloxin is the first anticancer

*email: lucia.pintilie@gmail.com 
agent that shows potent cytotoxicity towards eukaryotic cancer cell lines, but this compound has no antibacterial activity [6]). Fluoroquinolones, i.e. moxifloxacin, (1-cyclopropyl-7-[(1S,6S)-2,8-diazabicyclo[4.3.0]nonan-8-yl]-6-fluoro-8-methoxy-4-oxoquinoline-3-carboxylic acid (1), are part of the anti-tuberculosis agents of the second line [12]. Numerous quinolone derivatives have been screened for the anti-HIV activity in the last three decades. One of these compound is the quinolone K-12 (8difluoromethoxy-1-ethyl-6-fluoro-1,4-dihydro-7-[4-(2-methoxyphenyl)-1-piperazinyl]-4-quinolone -3carboxylic acid (5) who inhibit human immunodeficiency virus (HIV) replication at the transcriptional level [19]). The first integrase inhibitors drug with quinolone structure, who has already been approved by the U.S. Food and Drug [22] is Elvitegravir (6-[(3-chloro-2-fluorophenyl)methyl]-1-[(2S)-1hydroxy-3-methylbutan-2-yl]-7-methoxy-4-oxo-quinoline-3-carboxylic acid (6).<smiles>CNC1CN(c2ccc3c(=O)c(C(=O)O)cn(-c4nccs4)c3n2)CC1OC</smiles>

4. Voreloxin

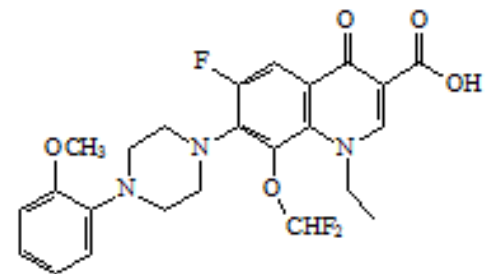

5. K-12<smiles>COC1=CC2C(CC1Cc1cccc(Cl)c1F)C(=O)C(C(=O)O)=CN2[C@@H](CO)C(C)C</smiles>

6. Elvitegravir

Fluoroquinolones are also, antibacterial agents used in the treatment of some bacterial infections, including hospital acquired infections and the infections caused by bacterial pathogens multi drug resistant [23-27]. Infections caused by Gram-positive rods are occasional in comparison with the infections caused by Gram-positive cocci or Gram-negative rods. It was observed that Gram-positive spore-forming rods (Bacillus spp.) are common contaminants of cultures but they may cause grave infections such as septicemia, endocarditis, endophthalmitis and wound infections. The most common species, Bacillus cereus, is resistant to $\beta$-lactam antibiotics, but it has been treated effectively with clindamycin, ciprofloxacin, vancomycin, and imipenem. Food poisoning caused by the Bacillus cereus does not need antibiotic treatment [28,29].

In this work we have realized design studies of some bicyclic quinolone compounds [30-32]. The most common substituents attached to the quinolone ring are shown in Figure 1.

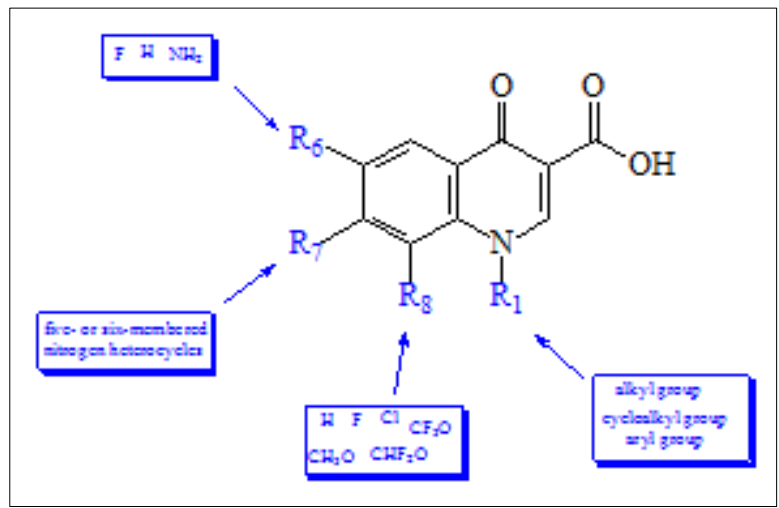

Figure 1. General structure of bicyclic quinolone compounds

Many quinolone compounds contain fluorine atom in 6 position, because C-6 fluorine is quite crucial for both high DNA gyrase complex binding activity and great bacterial cell penetration of the quinolone derivatives [33]. We have extended our research to design and synthesis new 6,8-dichloro-quinolone compounds for evaluated the influence of the nature of the halogen atom from six position of the quinolone ring on the molecular properties and on the antimicrobial activity. For the new quinolones was chosen an ethyl group for $\mathrm{N}-1$ position and a piperidinyl moiety for 7 position. The introduction of the chlorine atom at 8 position was motivated by the fact that the presence of this halogen atom in this position leads to a decrease in toxicity [34]. 


\section{Materials and methods}

\subsection{Molecular modeling}

Molecular, topological, conformational characteristics on 3D optimized structure have been calculated using Spartan 14 Software [35]. The DFT/B3LYP/6-311G* level of basis set has been used for the computation of molecular structure, vibrational frequencies, and energies of optimized structures.

\subsection{Docking studies}

Molecular docking studies was realized using CLC Drug Discovery Workbench Software. In the docking simulation the quinolone compounds (ligands) was fitted into predictable binding site on the surface of the protein target. The score docking and hydrogen bonds formed with the amino acid residues from the active site of the receptor are used to predict the binding modes, the binding affinities and the orientation of the ligands in the active site of the protein-receptor. The protein-ligand complex has been realized based on the X-ray structure of Bacillus cereus, who was taken from the Protein Data Bank (PDB ID: 1VEN) [36].

\subsection{Chemistry}

Melting points were determined in opened capillary on Melting point apparatus OptiMelt and are uncorrected. Thin layer chromatography (TLC) was performed on Merck silica gel 60F254 plates eluted with the solvent system: tetrahydrofuran: dioxan: $25 \%$ ammonia (60:20:30) (v:v:v) and were developed under UV light (254 nm). ${ }^{1} \mathrm{H}$ - and ${ }^{13} \mathrm{C}-\mathrm{NMR}$ spectra was recorded in $\mathrm{CDCl}_{3}$, DMSO-d 6 and trifluoroacetic acid, on two instruments Varian, Varian Gemini $300 \mathrm{BB}$ (operating at $300 \mathrm{MHz}$ for proton and $75 \mathrm{MHz}$ for carbon) and UNITY 400 Plus (operating at $400 \mathrm{MHz}$ for proton and $100 \mathrm{MHz}$ for carbon), (Tetra methyl silane as internal standard - the reference for the chemical shifts). All chemical shifts are given in the delta scale (ppm vs internal TMS). FT IR were recorded on an instrument Bruker Vertex 70 with diamond optic. UV-Vis were recorded on an instrument UV-Vis LAMBDA 12. Elemental analysis was performed on a Perkin Elmer CHNS/O Analyzer 2400 Series II.

Synthesis of 1-ethyl-6-chloro-7-(piperidin-1-yl)-1,4-dihydro-4-oxo-quinoline-3-carboxylic acid. (6CIPQ32). A mixture of 1-ethyl-6,7-dichloro-1,4-dihydro-4-oxo-quinoline-3-carboxylic acid (6ClQA) [37] (Scheme 1) $(2.86 \mathrm{~g}, 0.01 \mathrm{~mol})$, piperidine $(4.25 \mathrm{~g}, 0.05 \mathrm{~mol})$ and DMF $(30 \mathrm{~mL})$ was stirred $5 \mathrm{~h}$ at $110^{\circ} \mathrm{C}$. After $8 \mathrm{~h}, \mathrm{H}_{2} \mathrm{O}(30 \mathrm{~mL})$ and acetic acid $(p \mathrm{H}=7)$ were added and the resulting precipitate was filtered off. The crude product was recrystallized from DMF to yield $6 \mathrm{ClPQ} 32$ (m.p. 234.4-236.4 ${ }^{\circ} \mathrm{C}$; yield 53\%). ${ }^{1} \mathrm{H}-\mathrm{NMR}(\mathrm{dmso}-\mathrm{d} 6, \delta \mathrm{ppm}, \mathrm{J} \mathrm{Hz}): 8.97(\mathrm{~s}, 1 \mathrm{H}, \mathrm{H}-2) ; 8.20(\mathrm{~s}, 1 \mathrm{H}, \mathrm{H}-5) ; 7.28(\mathrm{~s}, 1 \mathrm{H}, \mathrm{H}-8)$; 4.58(q, 2H, H-17, 7.1); 3.18(m, 4H, 2H-20, 2H-24); 1.72(bs, 4H, 2H-21, 2H-23); 1.62(bs, 2H, H-22); 1.42(t, 3H, H-18, 7.1). ${ }^{13} \mathrm{C}-\mathrm{NMR}$ (dmso-d6, $\delta \mathrm{ppm}$ ): 176.01(C-4); 165.75(C-19); 154.61(C-9); 148.99(C2); 139.16(C-9); 127.04(C-5); 120.41(C-3); 107.90(C-8); 107.73(C-10); 51.84(C-20, C-24); 48.86(C17); 25.44(C-21, C-23); 23.49(C-22); 14.17(C-18). (*the numbering of the atoms was done according to the Scheme 1) FT-IR(solid in ATR, $v \mathrm{~cm}^{-1}$ ): 3035w; 2990w; 2951m; 2937m; 2917m; 2842w; 1722vs; $1608 \mathrm{~s} ; 1513 \mathrm{~s} ; 1486 \mathrm{~m} ; 1462 \mathrm{vs} ; 1443 \mathrm{vs} ; 1388 \mathrm{~m} ; 1373 \mathrm{~s} ; 1340 \mathrm{~m} ; 1297 \mathrm{~m} ; 1256 \mathrm{~m} ; 1240 \mathrm{vs} ; 1197 \mathrm{sm}$; 1091m; 1061m; 1032m; 985m; 949m; 914w; 899m; 863m; 843w; 823w;805m; 750w; 687m; 528w. Elemental Analyses: Calculated for: $\mathrm{C}_{17} \mathrm{H}_{19} \mathrm{ClN}_{2} \mathrm{O}_{3}: \mathrm{C}, 60.99 \% ; \mathrm{H}, 5.72 \% ; \mathrm{N}, 8.37 \%$. Found: C, 60.89\%; $\mathrm{H}, 5.69 \%$;, $8.40 \%$. UV-Vis $\left(\mathrm{CHCl}_{3}, \lambda\right.$ max $): 291.77 \mathrm{~nm}\left(\pi \rightarrow \pi^{*}\right)$.

Synthesis of 1-ethyl-6,8-dichloro-7-(piperidin-1-yl)-1,4-dihydro-4-oxo-quinoline-3-carboxylic acid (6ClPQ-33) $2.56 \mathrm{~mL} \mathrm{SO}_{2} \mathrm{Cl}_{2}$ were added to a solution of 6CIPQ-32 (3.35 g; $\left.0.01 \mathrm{~mol}\right)$ in $\mathrm{CHCl}_{3}(50 \mathrm{~mL})$ and the mixture was stirred at room temperature. After $30 \mathrm{~min}$ the mixture was washed with water. The $\mathrm{CHCl}_{3}$ layer was dried over $\mathrm{Na}_{2} \mathrm{SO}_{4}$ and was evaporated to dryness. The crude quinolone was recrystallized from DMF to yield 6ClPQ-33 (m.p. 214.6-216.30C, yield 76\%). 1H-NMR(dmso-d6, $\delta$ ppm, J Hz): 8.94(s, 1H, H-2); 8.26(s, 1H, H-5); 4.80(q, 2H, H-17, 7.1); 3.27(m, 4H, H-20, H-24); 1.69(m, $6 \mathrm{H}, \mathrm{H}-21, \mathrm{H}-22, \mathrm{H}-23) ; 1.38(\mathrm{t}, 3 \mathrm{H}, \mathrm{H}-18,7.1)$. 13C-NMR (dmso-d6, $\delta \mathrm{ppm}): 176.00(\mathrm{C}-4) ; 166.03(\mathrm{C}-$ 19);153.44(C-6);149.17(C-2);138.81(C-7);134.44(C-9);125.87(C-10);112.60(C-8);108.75(d,C-5); 
108.05(C-3);61.72(C-17);53.16(d, C-20, C-24); 26.12(C-21, C-23);23.73 (C-22);15.52 (C-18) (*).FTIR(solid in ATR, $v \mathrm{~cm}^{-1}$ ): 3048w; 2976w; 2934w; 2864w; 1714vs; 1652vs; 1611vs; 1545m; 1489s; $1437 \mathrm{vs} ; 1409 \mathrm{vs} ; 1383 \mathrm{vs} ; 1367 \mathrm{vs} ; 1331 \mathrm{~s} ; 1312 \mathrm{~m} ; 1276 \mathrm{~m} ; 1263 \mathrm{~m} ; 1228 \mathrm{~s} ; 1172 \mathrm{~s} ; 1120 \mathrm{~m} ; 1096 \mathrm{~m} ; 1083 \mathrm{~m}$; 1020m; 963m; 917m; 900m; 867m; 838m; 802m; 713m; 661w; 591w. Elemental Analyses: Calculated for: $\mathrm{C}_{17} \mathrm{H}_{18} \mathrm{Cl}_{2} \mathrm{~N}_{2} \mathrm{O}_{3}$ : C, 55.30\%; H, 4.91\%; N, 7.59\%. Found: C, 55.21\%; H, 4.80\%; N, 7.64\%. UV-Vis (CHCl3, $\lambda$ max.): $308.38 \mathrm{~nm}\left(\pi \rightarrow \pi^{*}\right)$.

Synthesis of 1-ethyl-6,8-dichloro-7-(3-methyl-piperidin-1-yl)-1,4-dihydro-4-oxo-quinoline -3carboxylic acid (6CIPQ-30) $2.56 \mathrm{~mL} \mathrm{SO}_{2} \mathrm{Cl}_{2}$ was added to a solution of 6ClPQ-24 [37] $(3,49 \mathrm{~g} ; 0,01$ $\mathrm{mol})$ in $\mathrm{CHCl}_{3}(50 \mathrm{~mL})$ and the mixture was at room temperature. After $30 \mathrm{~min}$ the mixture was washed with water. The $\mathrm{CHCl}_{3}$ layer was dried over $\mathrm{Na}_{2} \mathrm{SO}_{4}$, and was evaporated, to dryness. The crude quinolone was recrystallized from DMF to yield 6ClPQ-30 (m.p.190.3-192.20C; yield - 60\%). ${ }^{1} \mathrm{H}$ $\mathrm{NMR}\left(\mathrm{CDCl}_{3}+\mathrm{tfa}, \delta\right.$ ppm, J Hz): 8.59(s, 1H, H-2); 8.32(s, 1H, H-5); 4.62(q, 2H, H-17, 7.1); 3.20-2.80(m, 4H, H-20, H-24); 1.95-1.80(m,5H,2H-21,2H-22, H23); 1.48(t, 3H, H-18, 7.1); 0.85(d, 3H, H-25, 6.3). 13C-NMR(CDCl $3+\mathrm{tfa}, \delta \mathrm{ppm}): 176.65(\mathrm{C}-4) ; 165.43(\mathrm{C}-19) ; 152.92(\mathrm{C}-7) ; 151.41(\mathrm{C}-2) ; 139.24(\mathrm{C}-6)$; 132.46(C-8); 127.12(Cq); 126.87(C-5); 125.24(Cq); 109.52(Cq); 59.13(C-20); 53.51(C-17); 51.59(C24); 32.79(C-22); 31.69(C-23); 26.14(C-21); 19.20(C-25); 15.86(C-18) (*). FT-IR(solid in ATR, $v \mathrm{~cm}^{-}$ 1): $3050 \mathrm{~m} ; 2925 \mathrm{~s} ; 2840 \mathrm{~m} ; 1717 \mathrm{vs} ; 1610 \mathrm{vs} ; 1547 \mathrm{~s} ; 1492 \mathrm{vs} ; 1433 \mathrm{vs} ; 1404 \mathrm{vs} ; 1381 \mathrm{~s} ; 1357 \mathrm{~s} ; 1281 \mathrm{~m}$; 1263m; 1240m; 1210m; 1192m; 1144w; 1119w; 1090m; 1068w; 1022w; 973w; 923m; 851w; 834w; $801 \mathrm{~m} ; 714 \mathrm{~m}$. Elemental Analyses: Calculated for: $\mathrm{C}_{18} \mathrm{H}_{20} \mathrm{Cl}_{2} \mathrm{~N}_{2} \mathrm{O}_{3}: \mathrm{C}, 56.41 \%$; H, 5.26\%; N, 7.31\%. Found: C, 56.28\%; H, 5.20\%; N, 7.39\%. UV-Vis $\left(\mathrm{CHCl}_{3}, \lambda\right.$ max): $309.58 \mathrm{~nm}\left(\pi \rightarrow \pi^{*}\right)$.

\subsection{Minimum inhibitory concentration (MIC) determination}

All the quinolone compounds: 6CIPQ30, 6CIPQ33, FPQ30 and FPQ33 have been screened for their in vitro antibacterial activity against a variety of bacteria: Escherichia coli ATCC 8739, Staphylococcus aureus ATCC 6538, Pseudomonas aeruginosa ATCC 9027, Bacillus Subtilis ATCC 6633, Bacillus Cereus IP 64 and Micrococcus luteus ATCC 9341 by using a standard twofold serial dilution method with agar media [38].

\section{Results and discussions}

\subsection{Ligand preparation}

The ligands (quinolone derivatives) have been prepared using SPARTAN'14 software package [35]. The DFT/B3LYP/6-311 G* level of basis set has been used for the computation of molecular structure, vibrational frequencies and energies of optimized structures (Figure 2). To realized structure-activity relationship (SAR) studies, some electronic properties, such as HOMO (Highest Occupied Molecular Orbital) and LUMO (Lowest Unoccupied Molecular Orbital) energy values, HOMO and LUMO orbital coefficients distribution, molecular dipole moment, polar surface area (PSA) (a descriptor who allows the prediction of transport properties of the drugs because has been shown to correlate well with passive molecular transport through membranes), the ovality, polarizability (descriptor useful to predict the interactions between non-polar atoms or groups and other electrically charged species), the octanol water partition coefficient $(\log \mathrm{P})$ (Table 1$)$ habe been calculated. Table 1 display also chemical potential $(\mu)$ and electronegativity $(\chi)$ as well as global (softness $(S)$, hardness $(\eta)$ and electrophilicity index $(\psi)$ [3941]. The chemical softness (S) parameter for fluoroquinolones (FPQ30, FPQ33) is less than chloroquinolones (6ClPQ30, 6ClPQ33), therefore the stability of fluoroquinolones is grate than chloroquinolones. The positive value of electrophilicity $(\psi)$ shows the tendency of the system to accept electron from the environment. The electrophilicity increases in the order FPQ33<6ClPQ33<FPQ30<6ClPQ30. The FPQ33 is more stable because this fluoroquinolone possesses the smallest value of the electrophilicity from all the compounds. 


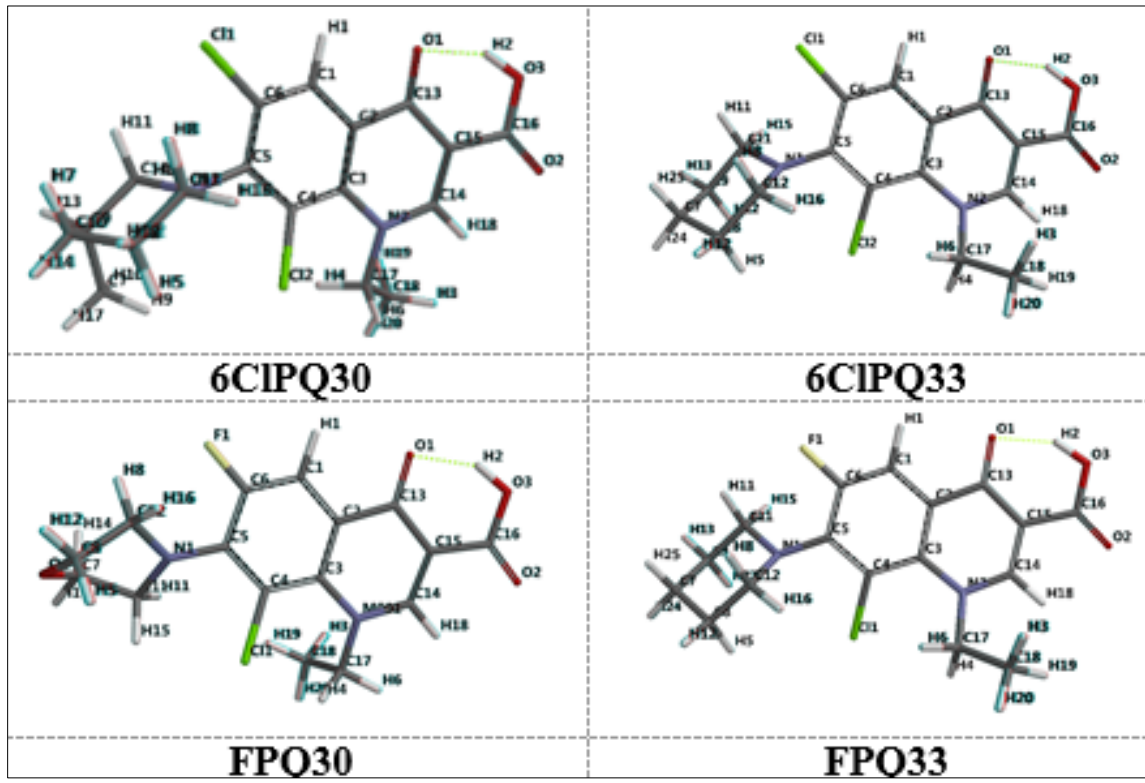

Figure 2. 3D Optimized structure of quinolone derivatives, tube Representation (designed with SPARTAN 14 Software, the numbering of the atoms was done according to the software)

Table 1. Predicted molecular properties for quinolone derivatives, using DFT method,

B3LYP model, 6-311G* basis set, in vacuum, for equilibrium geometry at ground state

\begin{tabular}{|c|c|c|c|c|}
\hline Molecular properties & 6CIPQ30 & 6CIPQ33 & FPQ30 & FPQ33 \\
\hline Еномо $(\mathrm{eV})$ & -6.41634271 & -6.34423877 & -6.45248237 & -6.37301620 \\
\hline Elumo $(\mathrm{eV})$ & -2.35300322 & -2.24491337 & -2.25329895 & -2.16997848 \\
\hline Energy band gap |Еномо- ELumol & 4.06333949 & 4.09932540 & 4.19918342 & 4.203033772 \\
\hline Ionization potential $\left(I=-\mathrm{E}_{\text {HOмо }}\right)$ & 6.41634271 & 6.34423877 & 6.45248237 & 6.37301620 \\
\hline Electron affinity $\left(A=-\mathrm{E}_{\mathrm{LUMO}}\right)$ & 2.35300322 & 2.24491337 & 2.25329895 & 2.16997848 \\
\hline Chemical hardness $(\eta=(I-A) / 2)$ & 2.0316698 & 2.0496627 & 2.0995917 & 2.10151689 \\
\hline Chemical softness $(S=1 / 2 \eta)$ & 0.24610299 & 0.24394258 & 0.23814154 & 0.23792338 \\
\hline Electronegativity $(\chi=(I+A) / 2)$ & 4.38467297 & 4.29457607 & 4.35390613 & 4.27149734 \\
\hline Chemical Potential $(\mu=-(I+A) / 2)$ & -4.38467297 & -4.29457607 & -4.35390613 & -4.27149734 \\
\hline Electrophilicity index $\left(\psi=\mu^{2} / 2 \eta\right)$ & 4.73141785 & 4.49912652 & 4.51432974 & 4.34107611 \\
\hline Energy [au] & -1953.83186 & -1914.51315 & -1593.47941 & -1554.16063 \\
\hline Dipole Moment [Debye] & 8.44 & 9.38 & 8.68 & 9.54 \\
\hline Polarizability $\left[10^{-30} \mathrm{~m}^{3}\right]$ & 69.00 & 67.48 & 68.20 & 66.69 \\
\hline $\mathrm{PSA}\left[\AA^{2}\right]$ & 44.261 & 44.003 & 44.553 & 44.386 \\
\hline Ovality & 1.51 & 1.48 & 1.49 & 1.46 \\
\hline $\log P$ & 4.08 & 3.68 & 3.68 & 3.28 \\
\hline Area $\left[\AA^{2}\right]$ & 364.40 & 343.81 & 353.87 & 333.90 \\
\hline Volume $\left[\AA^{3}\right]$ & 352.44 & 333.71 & 342.89 & 324.35 \\
\hline HBD & 1 & 1 & 1 & 1 \\
\hline HBA & 4 & 4 & 4 & 4 \\
\hline
\end{tabular}

Frontier molecular orbital analysis Frontier molecular orbital's (FMOs) show a decisive role in the chemical stability of a compound and in the interactions between atoms and are considered to be operative in determining characteristics of the compounds such as optical properties and biological activities. The most important FMOs are the highest occupied molecular orbital (HOMO) and the lowest unoccupied molecular orbital (LUMO). The HOMO represents the ability of a molecule to donate an electron, while the LUMO is an electron acceptor. The graphic has "blue and red" regions that are corelated to positive and negative values of the orbitals. Figure 3 displays distribution and energy levels of the HOMO and LUMO orbitals. For the HOMO of 6CIPQ33, electron density is localized on piperidine heterocyclic (N1, C-11, C-12), on C-6, C-5, C-4 and C-2 atoms from aromatic ring, on O-1, $\mathrm{Cl}-1$ and on $\mathrm{Cl}-2$, on the same as with fluoroquinolones FPQ 30 and FPQ33. In the case of quinolone 
6CIPQ30, electron density is localized on piperidine heterocyclic (N, C-11, C-12), on C-6, C-5 and C-8 atoms from aromatic ring, and on chlorine atom, Cl-2. For the LUMO of 7-substituted-8-chlorquinolones 6CIPQ30 and 6CIPQ33, electron density is localized on 4-piridinona ring, on aromatic ring and on chlorine atom (Cl-2), on the same as with fluoroquinolones FPQ 30 and FPQ 33. The frontier orbital gap $(\Delta \mathrm{E})$ give information about the chemical reactivity of the molecule. The higher value of HOMO-LUMO gap $(\Delta \mathrm{E})$, for the all compounds, shows the all quinolones have a chemically stable molecule.

Molecular Electrostatic Potential (MEP) is important for the determination of the reactive sites of nucleophilic or electrophilic attack in hydrogen-bonding interactions and for the figure out of the process of biological recognition. An electrostatic potential map displays hydrophilic regions in red (negative potential) and blue (positive potential) and hydrophobic regions in green. The electrostatic potential increases in the order red<orange<yellow<green<blue. Figure 4 showed the molecular electrostatic potential maps of quinolone compounds 6ClPQ30 and 6ClPQ33 and fluoroquinolones FPQ30 and FPQ33 for B3LYP/ 6-311G* levels. For all compounds, red regions are localized on the $\mathrm{O}$ atoms and the blue regions are localized on $\mathrm{N}$ atoms.

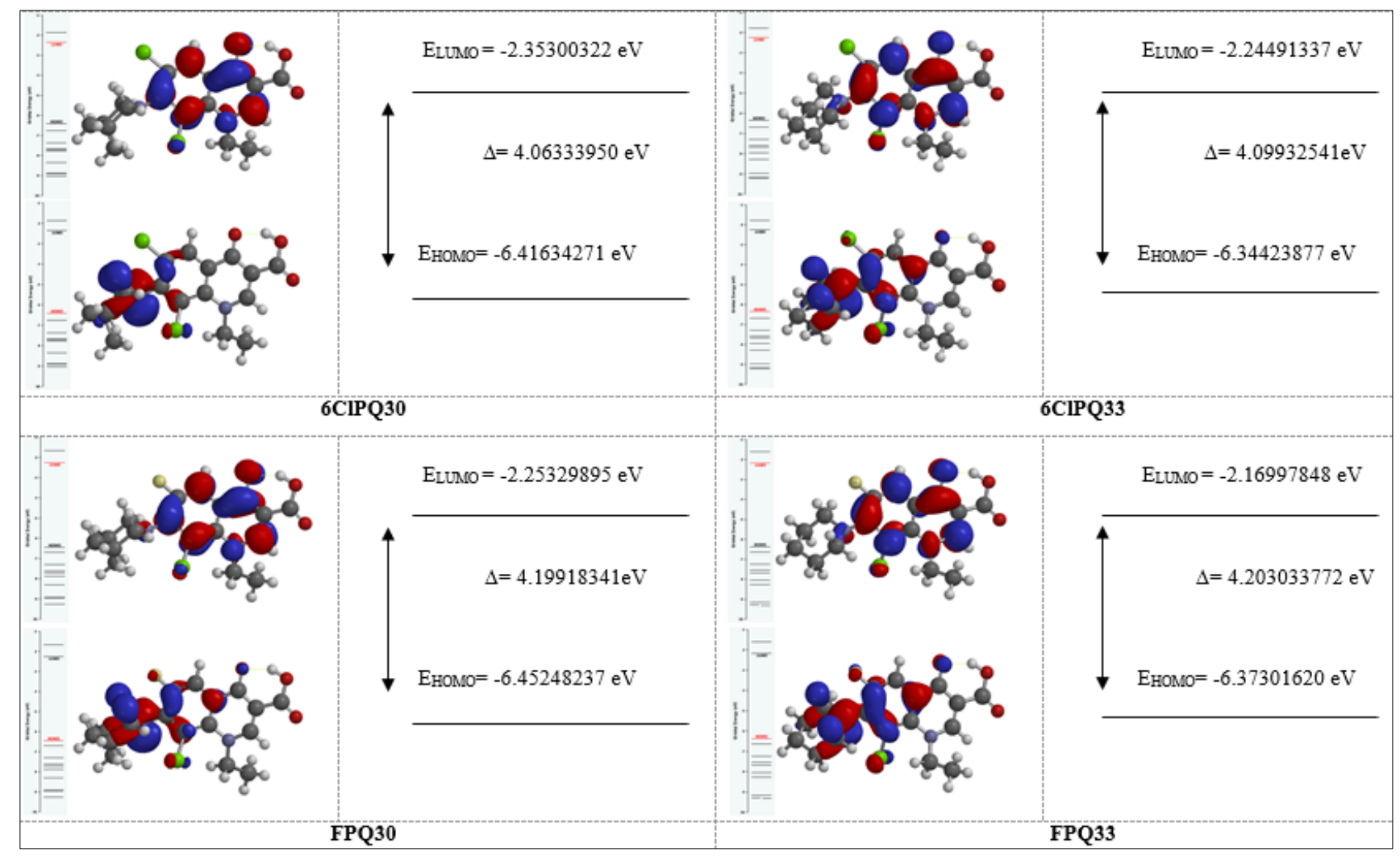

Figure 3. The HOMO and LUMO molecular orbital diagram

Mulliken population analysis The Mulliken population analysis of the quinolone compounds has been calculated using B3LYP/6-311G* level. As the charge distribution of all quinolone compounds in Figure 5 shows, that carbon atoms from ethyl group $(\mathrm{C} 17, \mathrm{C} 18)$ attached to nitrogen atom $(\mathrm{N} 2)$ are negative, whereas all the hydrogen atoms have positive charges. The oxygen atoms (O1, O2 and O3) have negative charges. The carbon atom $(\mathrm{C} 16)$ from carboxylic group has great positive charges. Also, carbon atom (C13) from keto group has positive charges. The fluorine atom (atom with a high electron affinity) has negative charge (F1 from FPQ30: -0.223 and FPQ33: -0.226) and induce an unusually large positive charge on the carbon atom C6 (FPQ30: +0.359, FPQ33: +0.313). For 6ClPQ30 and 6ClPQ33 the carbon $\mathrm{C} 6$ atom has negative charge $(-0.158$ respective $-0,209)$. The influence of electronic effect 
resulting from the hyperconjugation and induction of methyl group in the piperidine heterocycle causes a large negative charged value in the carbon atoms C7 in 6ClPQ30(-0.614) and in FPQ30 (-0.615).

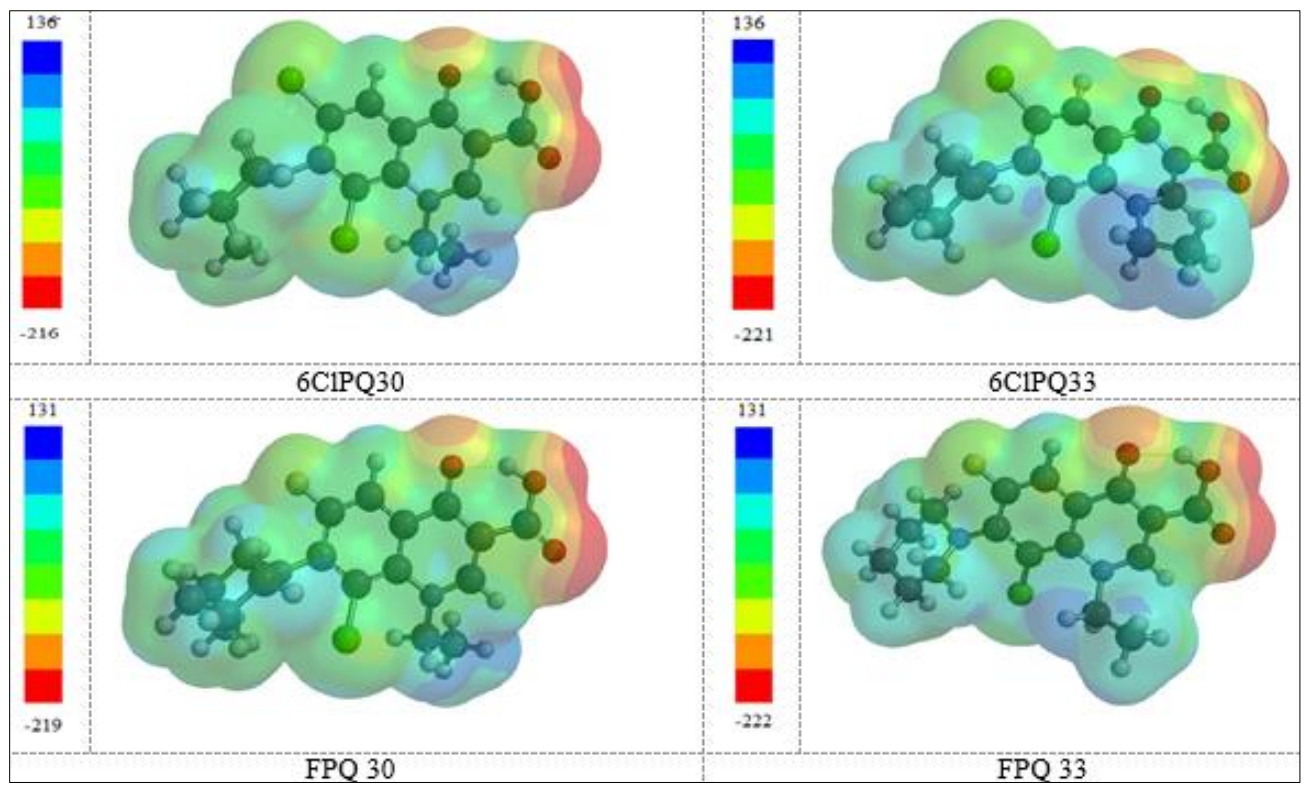

Figure 4. The optimized geometry and electrostatic potential map of quinolone derivatives

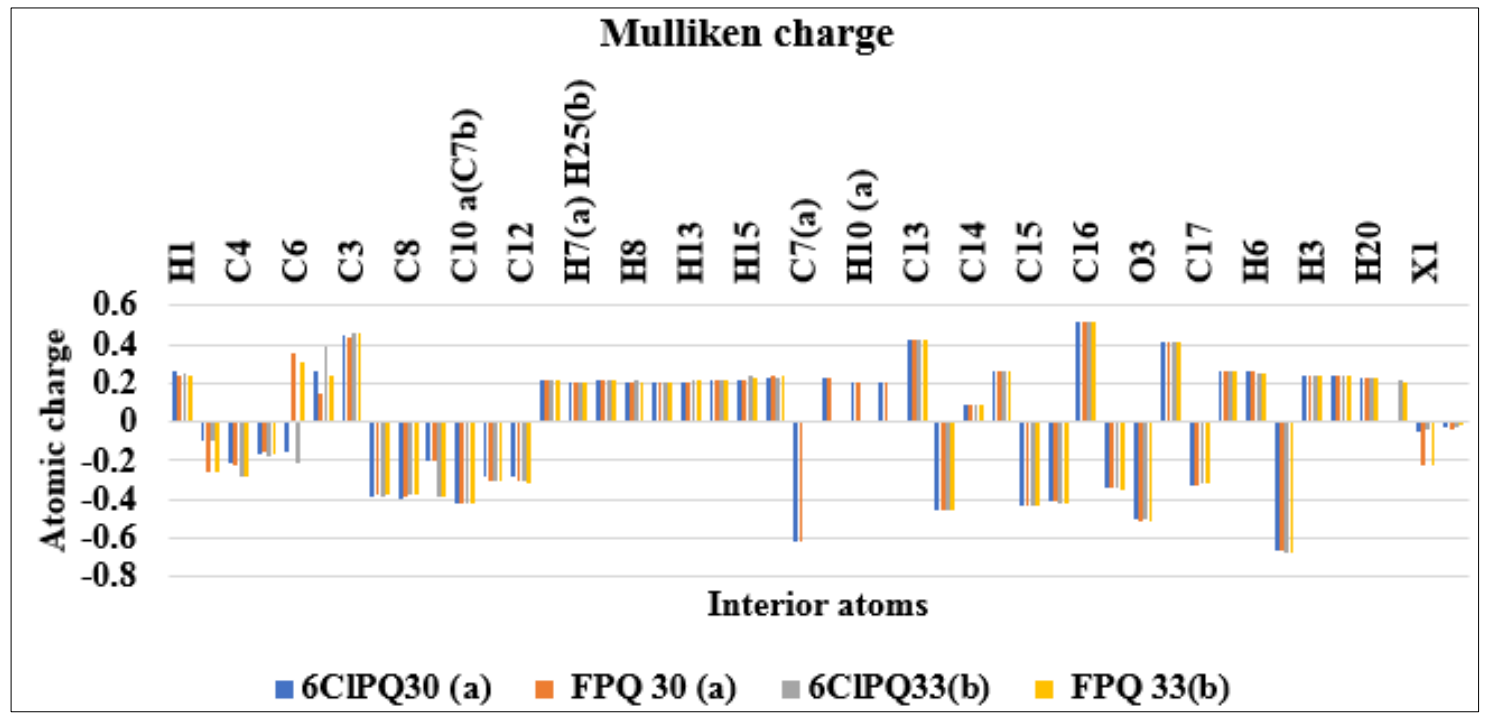

6ClPQ30: $\mathrm{X} 1=\mathrm{X} 2=\mathrm{Cl}$; 6ClPQ33: $\mathrm{X} 1=\mathrm{X} 2=\mathrm{Cl}$; $\mathrm{FPQ30}: \mathrm{X} 1=\mathrm{F} ; \mathrm{X} 2=\mathrm{Cl}$; FPQ33: $\mathrm{X} 1=\mathrm{F} ; \mathrm{X} 2=\mathrm{Cl}$

Figure 5. The Mulliken charge diagram of quinolone compounds

\subsection{Docking studies}

In the docking simulation, the quinolone compounds (ligands) was fitted into predictable binding site on the surface of the protein target. The score docking and hydrogen bonds formed with the amino acid residues from the active site of the receptor are used to predict the binding modes, the binding affinities, and the orientation of the ligands in the active site of the receptor. The protein-ligand complex has been realized based on the X-ray structure of Bacillus cereus, who was imported from the Protein Data Bank (PDB ID: 1VEN). All investigated compounds have been virtually docked on Bacillus Cereus according to the protocol described in previous works $[42,43]$. 


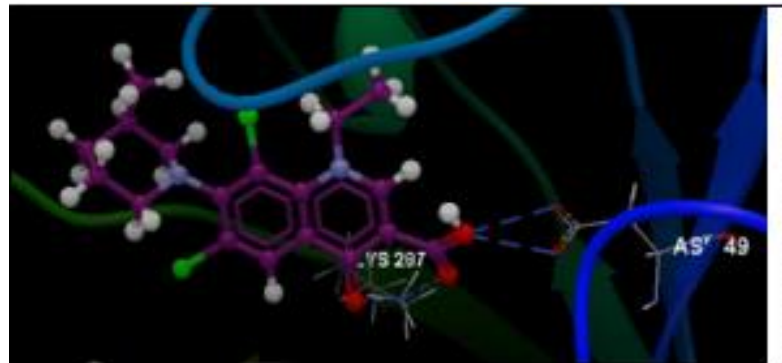

Figure 6a. Docking pose of the compound $6 \mathrm{CIPQ} 30$ in the binding site of $1 \mathrm{VEN}$

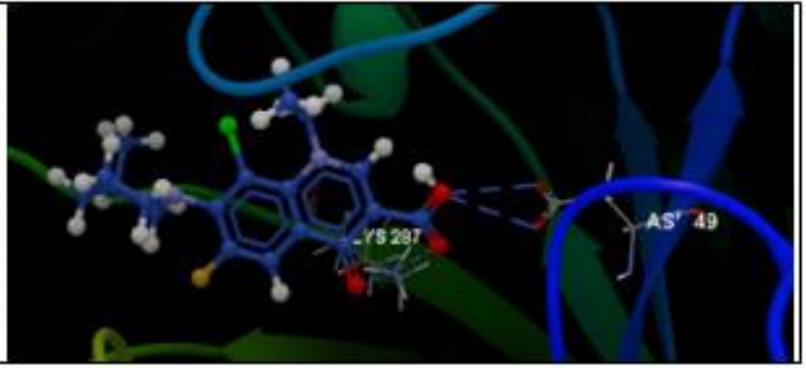

Figure $6 \mathrm{~b}$. Docking pose of the compound FPQ30 in the binding site of $1 \mathrm{VEN}$

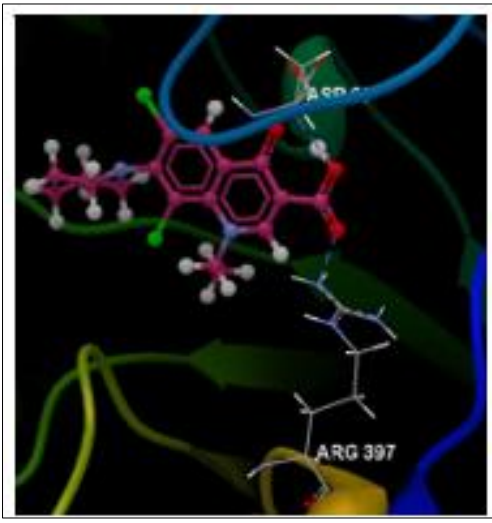

Figure 6c. Docking pose of the compound 6ClPQ33 in the binding site of 1 VEN

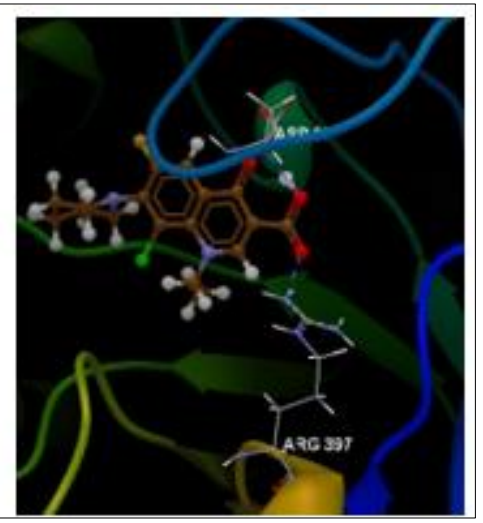

Figure 6d. Docking pose of the compound FPQ33 in the binding site of $1 \mathrm{VEN}$

The docking studies revealed that all the compounds presented good docking score (Table 2). The better score docking has been obtained from quinolone 6CIPQ 33 (score: -62.80; RMSD 0.04 $⿱$ ). 6ClPQ 33 displays the occurrence of two hydrogen bonds with ASP 97 (3.137 $\AA$ ) and ARG $397(3.092 \AA)$ (Figure 6a). Same hydrogen bonds with the same amino acids, ASP 97 (3.050 ̊) and ARG 397 (2.882 $\AA$ ) (Figure 6b) displays fluoroquinolone FPQ33 (score: -62.36; RMSD $0.02 \AA$ ). The 6CIPQ30 compound (score: -61.79; RMSD $0.04 \AA$ ) displays the occurrence of four hydrogen bonds, two with ASP 49 (2.647 $\AA$ and $3.203 \AA$ ) and two with LYS $287(2.878 \AA$ and $2.715 \AA$ ) (Figure 6c). Some orientation was observed for fluoroquinolone FPQ30 (score: -61.79; RMSD 0.13 $\AA$ ). But FPQ30 shows the occurrence of three hydrogen bonds, two with ASP 49 (3.087 $\AA$ and $3.229 \AA$ ) and one with LYS 287 (3.018 $\AA$ ) (Figure 6d). Table 2 also shows the amino acids residues from group of interaction of all compounds docked in the binding site of $1 \mathrm{VEN}$.

Table 2 The list of intermolecular interactions between the ligand molecules docked with 1VEN

\begin{tabular}{|c|c|c|c|c|c|}
\hline Ligand & Score & $\begin{array}{c}\text { RMSD } \\
\AA\end{array}$ & $\begin{array}{c}\text { Group } \\
\text { interaction }\end{array}$ & $\begin{array}{l}\text { Hydrogen } \\
\text { bond }\end{array}$ & $\begin{array}{l}\text { Bond } \\
\text { length }\end{array}$ \\
\hline 6ClPQ 30 & -61.79 & 0.04 & $\begin{array}{l}\text { GLY 92, ASN 94, ALA 170, ALA 369, LEU 370, } \\
\text { ASP 97, LYS 287, ILE 85, GLU 367, GLY 171, } \\
\text { ASN 368, GLU 172, ALA 289, ARG 174, THR } \\
\text { 330, HIS 89, GLY 290, CYS 331, PRO 169, TRP } \\
\text { 293, TYR 178, GLN 90, ASN 368, LEU 396, MET } \\
\text { 16, TRP 51, ASP 49, ARG 397, CYS 91, LEU } 19\end{array}$ & $\begin{array}{l}\mathrm{O} \mathrm{sp}^{2}(\mathrm{O} 3)-\mathrm{O} \mathrm{sp}^{2} \text { from ASP } 49 \\
\mathrm{Osp} \mathrm{sp}^{2}(\mathrm{O} 3)-\mathrm{O} \mathrm{sp}^{2} \text { from ASP } 49 \\
\mathrm{O} \mathrm{sp}(\mathrm{O} 2)-\mathrm{N} \mathrm{sp} \text { from LYS } 287 \\
\mathrm{Osp} \mathrm{sp}^{2}(\mathrm{O} 1)-\mathrm{N} \mathrm{sp} \text { from LYS } 287\end{array}$ & $\begin{array}{l}2.647 \AA \\
3.203 \AA \\
2.878 \AA \\
2.715 \AA\end{array}$ \\
\hline FPQ30 & -61.79 & 0.13 & $\begin{array}{l}\text { ASP 97, ASN 94, VAL 95, TYR 178, PRO 169, } \\
\text { ALA 170, ASP 49, LEU 19, TRP 51, HIS 89, GLY } \\
\text { 171, ILE 85, ARG 397, MET 16, LEU 396, LYS } \\
\text { 287, GLU 172, ARG 174, LEU 370, ALA 289, } \\
\text { ALA 369, GLU 367, ASN 369, THR 330, CYS 331, } \\
\text { GLY 290, VAL 291, HIS 292, TRP 293, MET } 334\end{array}$ & $\begin{array}{l}\mathrm{O} \mathrm{sp}^{2}(\mathrm{O} 3)-\mathrm{O} \mathrm{sp}^{2} \text { from ASP } 49 \\
\mathrm{O} \mathrm{sp}^{2}(\mathrm{O} 3)-\mathrm{O} \mathrm{sp}^{2} \text { from ASP } 49 \\
\mathrm{O} \mathrm{sp}^{2}(\mathrm{O} 2)-\mathrm{N} \mathrm{sp}^{3} \text { from LYS } 287\end{array}$ & $\begin{array}{l}3.087 \AA \\
3.229 \AA \\
3.018 \AA\end{array}$ \\
\hline
\end{tabular}




\begin{tabular}{|c|c|c|c|c|c|}
\hline 6CIPQ 33 & -62.80 & 0.04 & $\begin{array}{l}\text { ASP 97, LEU 19, TRP 51, ASP 49, ASN 94, VAL } \\
\text { 95, ARG 397, ALA 170, LEU 396, LEU 370, TYR } \\
\text { 178, GLU 172, ALA 369, ARG 174, ALA 289, } \\
\text { ASN 368, GLU 367, CYS 331, THR 330, LYS 287, } \\
\text { GLY 290, VAL 291, HIS 292, TRP } 293\end{array}$ & $\begin{array}{l}\mathrm{O} \mathrm{sp}^{2}(\mathrm{O} 3)-\mathrm{O} \mathrm{sp}^{2} \text { from ASP } 97 \\
\mathrm{O} \mathrm{sp}{ }^{2}(\mathrm{O} 2)-\mathrm{N} \mathrm{sp} \text { from ARG } 397\end{array}$ & $\begin{array}{l}3.157 \AA \\
3.092 \AA\end{array}$ \\
\hline FPQ33 & -62.36 & 0.02 & $\begin{array}{l}\text { ASP 97, LEU 19, TRP 51, ASP 49, ASN 94, VAL } \\
\text { 95, ARG 397, ALA 170, LEU 396, LEU 370, TYR } \\
\text { 178, GLU 172, ALA 369, ARG 174, ALA 289, } \\
\text { ASN 368, GLU 367, CYS 331, THR 330, LYS 287, } \\
\text { GLY 290, VAL 291, HIS 292, TRP } 293\end{array}$ & 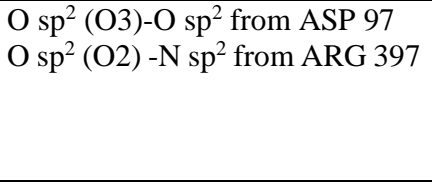 & $\begin{array}{l}3.050 \AA \\
2.882 \AA\end{array}$ \\
\hline
\end{tabular}

The synthesis of the quinolone derivatives is shown in Scheme1. The quinolone compounds were synthesized by the reaction of the compound (1) (QA: R6= F, 6ClQA: R6=Cl) [37] with piperidine or 4-methyl-piperidine. The 8-unsubstituted quinoline-3-carboxylic acid (FPQ32 [43], FPQ24 [37], 6ClPQ32, 6ClPQ24 [37] was chlorinated with sulfuryl chloride. The final quinolone compounds, 6CIPQ33, 6CIPQ30, FPQ33 [43] and FPQ30 [38] were analyzed by physic-chemical techniques (elemental analysis, 1H-NMR, 13C-NMR, FT IR, UV-Vis).

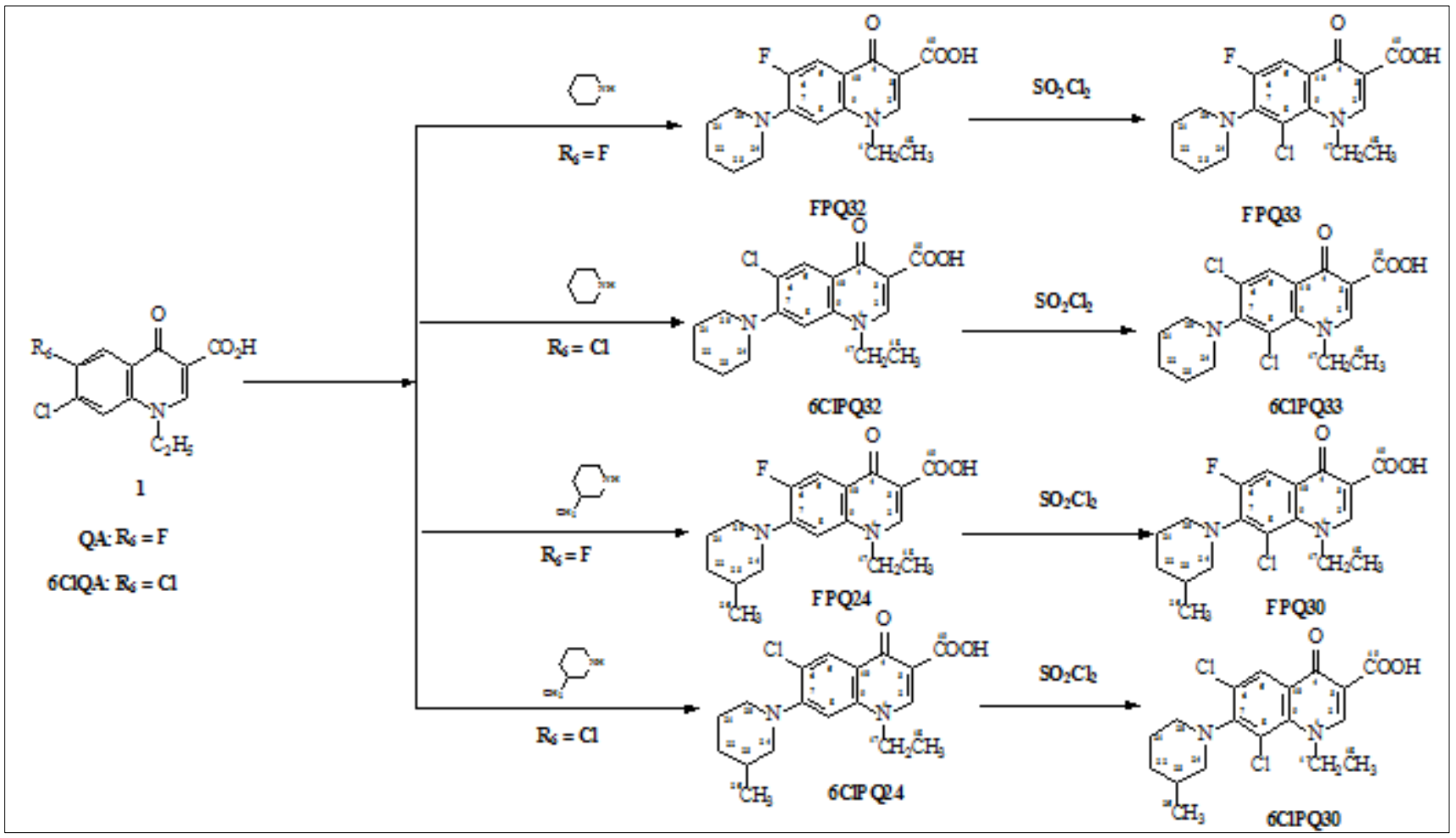

Scheme 1. Synthesis of quinolone compounds

Quinolone derivatives were evaluated for "in vitro" activity" by determining minimum inhibitory concentration against some Gram-positive: Staphylococcus aureus ATCC 29213, Bacillus cereus IP 64, Bacillus subtilis ATCC 6633, Micrococcus luteus ATCC 9341 and Gram-negative microorganisms: Pseudomonas aeruginosa ATCC 27853, Escherichia coli ATCC 25922 (Table 3). The introduction of a chlorine atom into the sixth position of the quinolone nucleus leads to the decrease of biological activity against Staphylococcus aureus, Escherichia coli and Pseudomonas aeruginosa, but does not affect the biological activity against Bacillus cereus, Bacillus subtilis and Micrococcus luteus. In the case of compound FPQ 30, a compound that has a good activity against all the studied microorganisms, the replacement of the fluorine atom with chlorine atom, leads to the improvement of the activity towards the Bacillus cereus. 
Table 3. Antibacterial activity "in vitro"

\begin{tabular}{|c|c|c|c|c|c|c|}
\hline \multirow[b]{2}{*}{ Compound } & \multicolumn{6}{|c|}{$\begin{array}{l}\text { Minimum inhibitory concentration (MIC) } \\
\mu \mathrm{g} / \mathrm{ml}\end{array}$} \\
\hline & $\begin{array}{c}\text { Escherichia } \\
\text { coli } \\
\text { ATCC 25922 } \\
\end{array}$ & $\begin{array}{c}\text { Staphylococcus } \\
\text { aureus } \\
\text { ATCC } 29213 \\
\end{array}$ & $\begin{array}{c}\text { Pseudomonas } \\
\text { aeruginosa ATCC } \\
27853 \\
\end{array}$ & $\begin{array}{l}\text { Bacillus Subtilis } \\
\text { ATCC } 6633\end{array}$ & $\begin{array}{l}\text { Bacillus } \\
\text { Cereus } \\
\text { IP 64 }\end{array}$ & $\begin{array}{c}\text { Micrococcus } \\
\text { luteus } \\
\text { ATCC } 9341\end{array}$ \\
\hline FPQ 30 & 0.32 & 0.125 & 1.28 & 0.125 & 0.015 & 0.015 \\
\hline FPQ-33 & 0.32 & 0,32 & 1.28 & 0.015 & 0.015 & 0.015 \\
\hline 6CIPQ-30 & 8.00 & 2.56 & 2.56 & 0.015 & 0.015 & 0.015 \\
\hline 6CIPQ-33 & 2.56 & 2.56 & 2.56 & 0.015 & 0.015 & 0.015 \\
\hline
\end{tabular}

\section{Conclusions}

Some 6,8-dichloro-quinolone compounds were designed and synthesized, and we studied the influence of the change of the fluorine atom from six position on the quinolone ring with a chlorine atom, on the molecular properties and on the antimicrobial activity. The quinolone compounds were characterized by physical-chemical methods (elemental analysis, IR spectral analysis, 1H-NMR, 13CNMR spectra, UV-Vis, thin layer chromatography) and by antimicrobial activity against some Grampositive and Gram-negative microorganisms: Staphylococcus aureus, Bacillus cereus, Bacillus subtilis, Micrococcus luteus, Escherichia coli and Pseudomonas aeruginosa. As a result of docking simulations, the score and hydrogen bonds formed with the amino acids residues were used to predict the binding modes, the binding affinities, and the orientation of the docked quinolone compounds. The docking studies reveals that the all compounds presented good docking score. The better score docking was obtained from quinolone 6CIPQ 33 score: -62.80 (RMSD $0.04 \AA$ ). A correlation of the predicted data with the experimental data obtained from the evaluation of the antimicrobial activity against Bacillus cereus of quinolone compounds were observed. In conclusion, structural modifications of this class of antimicrobial agents have afforded compounds with better activity against Bacillus cereus, Bacillus subtilis and Micrococcus luteus.

Acknowledgments: This paper has been financed through the NUCLEU Program, which is implemented with the support of Ministry of Education and Research, Project no. 19-41 0102

\section{References}

1.SUAIFAN, A.R.Y., MOHAMED, A.A.M., Bioorg. Med. Chem., 27(14), 2019, 3005-3060, https://doi.org/10.1016/j.bmc.2019.05.038

2.EZELARAB, H.A.A., ABBAS, S.H., HASSAN, H.A., ABUO-RAHMA, G.E-D.A., Arch. Pharm. Chem. Life. Sci., 351, 2018, e1800141, https://doi.org/10.1002/ardp.201800141

3.ZHANG, B., Arch. Pharm. Chem. Life. Sci., 352, 2019, e1800382, https://doi.org/10.1002/ardp.201800382

4.ZHOU, Y., WANG, J., GU, Z., WANG, S., ZHU, W., ACEÑA, J.L., SOLOSHONOK, V.A., IZAWA, K., HONG LIU, H., Chem. Rev., 116(2), 2016, 422-518, DOI: 10.1021/acs.chemrev.5b00392

5.XINNUO XIONG, X., HE, J., YANG, H., TANG, P., TANG, B., SUN, Q., LI, H., RSC Adv., 7, 2017, 48942-48951, https://doi.org/10.1039/C7RA08731D

6.JAMIESON, G.C., FOX, J.A., POI, M., STRICKLAND, S.A., Drugs, 76(13), 2016, 1245-1255,

DOI 10.1007/s40265-016-0614-Z

7.ABDEL-AZIZ, A.A.-M., EL-AZAB, A.S., ALANAZI, A.M., ASIRI, Y.A., AL-SUWAIDAN, I.A., AZZA R. MAAROUF, A.R., REZK R. AYYAD, R.R, TAGHREED Z. SHAWER, T.Z., J Enzyme Inhib Med Chem, 31(5), 2016, 796-809

8.HU, W., HUANG, X-S., WU, J-F., YANG, L., ZHENG, Y-T., SHEN, Y-M., LI, Z-Y., XUN LI, X., J. Med. Chem., 61(20), 2018, 8947-8980, https://doi.org/10.1021/acs.jmedchem.7b01202

9.YADAV, V., TALWAR, P., Biomed. Pharmacother., 111, 2019, 934-946, https://doi.org/10.1016/j.biopha.2018.12.119 
10.TAN, L., ZHANG, Z., GAO, D., LUO, J., TU, Z-C., LI, Z., PENG, L., REN, X., DING, K., J. Med. Chem., 59(14), 2016, 6807-6825, DOI: 10.1021/acs.jmedchem.6b00608

11.LI, J., ZHENG, T-C., JIN, Y., XU, J-G., YU, J-G., LV, Y-W., Chem. Pharm. Bull., 66(1), 2018, 5560, https://doi.org/10.1248/cpb.c17-00035

12.PRANGER, A.D., VAN DER WERF, T.S., KOSTERINK, J.G.W., ALFFENAAR, J.W.C., Drugs, 79, 2019, 161-171, https://doi.org/10.1007/s40265-018-1043-y

13.NJOGU, P.M., GUANTAI, E.M., PAVADAI, E., CHIBALE, K., ACS Infect. Dis., 2(1), 2016, 8-31, DOI: 10.1021/acsinfecdis.5b00093

14.FUKUDA, H., BKISHII, R., TAKEI, M., HOSAKA, M., Antimicrob. Agents Chemother., 45(6), 2001,1649-1653, DOI: 10.1128/AAC.45.6.1649-1653.2001

15.AUBRY, A., PAN, X-S., FISHER, L.M., JARLIER, V., CAMBAU, E., Antimicrob. Agents Chemother., 48(4), 2004, 1281-1288

16.CHIKHALE, R.V., BARMADE, M.A., MURUMKAR, P.R., YADAV, M.R., J. Med. Chem., 61(19), 2018, 8563-8593, DOI: 10.1021/acs.jmedchem.8b00281

17.MURATA, M., KOSAI, K., YAMAUCHI, S., SASAKI, D., KAKU, N., UNO, N., MORINAGA, Y., HASEGAWA, H., MIYAZAKI, T., IZUMIKAWA, K., MUKAE, H., YANAGIHARA, K., Antimicrob. Agents Chemother., 62(4),2018, e01971-17, https://doi.org/10.1128/AAC.01971-17

18.RICHTER, S.N., GATTO, B., TABARRINI, O., FRAVOLINI, A., PALUMBO, M., Bioorg. Med. Chem. Lett., 15(19), 2005, 4247-4251, doi:10.1016/j.bmcl.2005.06.074

19.WITVROUW, M., DAELEMANS, D., PANNECOUQUE, C., NEYTS, J., ANDREI, G., SNOECK, R., VANDAMME, A.M., BALZARINI, J., DESMYTER, J., BABA, M., DE CLERCQ, E., Antiviral Chem. Chemother., 9(5), 1998, 403-411, DOI: 10.1177/095632029800900504

20.PESCATORI, L., MÉTIFIOT, M., CHUNG, S., MASOAKA, T., CUZZUCOLI CRUCITTI, G., MESSORE, A., PUPO, G., MADIA, V.N., SACCOLITI, F., SCIPIONE, L., TORTORELLA, S., DI LEVA, F.S., COSCONATI, S., MARINELLI, L., NOVELLINO, E., LE GRICE, S.F.J., POMMIER, Y., MARCHAND, C., COSTI, R., DI SANTO, R., J. Med. Chem., 58(11), 2015, 4610-4623,

DOI: 10.1021/acs.jmedchem.5b00159

21.TABARRINI, O., MASSARI, S., DAELEMANS, D., MESCHINI, F., MANFRONI, G., BOTTEGA, L., GATTO, B., PALUMBO, M., PANNECOUQUE, C., CECCHETTI, V., ChemMedChem, 5(11), 2010, 1880-1892, DOI: $10.1002 / \mathrm{cmdc} .201000267$

22.WANG, R, XU, K., SHI, W., Arch. Pharm. Chem. Life. Sci., 352(9), 2019,

1900045https://doi.org/10.1002/ardp.201900045

23.TOWLE, T.R., KULKARNI, C.A., OPPEGARD, L.M., WILLIAMS, B.P., PICHA, T.A., HIASA, H., KERNS, R.J., Bioorg. Med. Chem. Lett., 28(10), 2018, 1903-1910,

https://doi.org/10.1016/j.bmcl.2018.03.085

24.KANT, R., SINGH, V., NATH, G., AWASTHI, S.K., AGARWAL, A., Eur. J. Med. Chem., 124, 2016, 218-222, https://doi.org/10.1016/j.ejmech.2016.08.031

25.ODAGIRI, T., INAGAKI, H., NAGAMOCHI, M., KITAMURA, T., KOMORIYA, S., TAKAHASHI, H., J. Med. Chem., 61(16), 2018, 7234-7244, DOI: 10.1021/acs.jmedchem.8b00644 26.DE SOUZA, M.V.N., Mini-Rev. Med. Chem., 5(11), 2005, 1009-1017, DOI: $10.2174 / 138955705774575246$

27. DA SILVA, A.D., DE ALMEIDA, M.V., DE SOUZA, M.V.N., COURI, M.R.C., Curr. Med. Chem., 10(1), 2003, 21-39, DOI: 10.2174/0929867033368637

28.VON GRAEVENITZ, A., Clin. Microbiol. Infect., 7(Supplement 4), 2001, 43-46,

DOI https://doi.org/10.1046/j.1469-0691.2001.00057.x

29.ANGELA T. NGUYEN, A.T., SANDRA M. TALLENT, S.M., 78, 2019, 164-170,

https://doi.org/10.1016/j.fm.2018.10.008

30.MITSCHER, L.A., Chem. Rev. 105, 2005, 559-592, https://doi.org/10.1021/cr030101q 31.PINTILIE L. Quinolones: Synthesis and Antibacterial Activity. In: Bobbarala V. editor. Antimicrobial agents. Ed. INTECH; 2012, 255-272. DOI: 10.5772/33215 
32.AHMED, A., DANESHTALAB, M., J. Pharm. Pharmaceut. Sci., 15(1), 2012, 52-72

33.ZHOU, Y., WANG, J., GU, Z., WANG, S., ZHU, W., ACEÑA, J.L., SOLOSHONOK, V.A, IZAWA, U., LIU, H., Chem. Rev. 116(2), 2016, 422-518, DOI: 10.1021/acs.chemrev.5b00392

34.EZELARAB, H.A.A., ABBAS, S.H., HASSAN, H.A., GAMAL EL-DIN A. ABUO-RAHMA, G.ED.A., Arch Pharm Chem Life Sci., 351(9), 2018, e1800141, https://doi.org/10.1002/ardp.201800141 35.***Spartan'14 Wavefunction, Inc. Irvine, CA

36.HIRATA, A., ADACHI, M., UTSUMI, S., MIKAMI, B., 43(39), 2004, 12523-12531, https://doi.org/10.1021/bi049173h

37.PINTILIE L., NEGUT C., ONISCU C., CAPROIU M.T., NECHIFOR M., IANCU L., GHICIUC C., URSU R., 14(5), 2009, 4756-4767

38.PINTILIE L, DOROBAT O, CAPROIU MT, MAGANU M., Rev. Chim., 65(10), 2014, 1176-1181

39.PEARSON, R.G., Absolute electronegativity and hardness: applications to organic chemistry, J. Org. Chem., 54(6), 1989, 1423-1430, https://doi.org/10.1021/jo00267a034

40.PADMANABHAN, J., PARTHASARATHI, R., SUBRAMANIAN, V., CHATTARAJ, P., J. Phys. Chem. A, 111(7), 2007, 1358-1361, https://doi.org/10.1021/jp0649549

41.ANTONINA GRITCO-TODIRASCU, A., CREANGA, D.E., LILIANA MIHAELA IVAN, L.M., DOROHOI, D.O., CIUBARA, A., Rev. Chim., 71(2), 2020, 121-127

42.PINTILIE, L., STEFANIU, A., NICU, A.I., CAPROIU, M.T., MAGANU, M., Rev. Chim., 67(3), 2016, 438-445

43.PINTILIE, L., STEFANIU, A., NICU, A.I., MAGANU, M., CAPROIU, M.T., Rev. Chim., 69(4), 2018, 815-822

Manuscript received: 11.10 .2019 